\title{
RECEPTION OF ISA 7:17 IN QUMRAN: THE USE OF AMBIGUITY OF THE BIBLICAL TEXT
}

\author{
L I B O R M A R E K
}

ABSTRACT

Verse 7:17 from Isaiah presents its interpreters, both ancient and modern, with difficulties and ambiguities regarding the text that must be accounted for on the level of formulation (problematic grammar), content (uncertain meaning) and incorporation into the larger context of Isa 7:1-17. The Damascus Document from Qumran uses this verse twice (in CD VII \& XIII) in texts of different types (Admonitions and Laws). The author of the Damascus Document resolves the ambiguities of the biblical verse and incorporates it into his two compositions for the benefit of his argumentation. This type of redactional work is possible due to a recognition by the author of a continuity between the biblical Israel and the current (Qumran) community. While resolving the problems inherent to the biblical verse, the author of the Damascus Document also creates a new tension between the ways in which this verse is incorporated into the two documents.

Key words

Syro-Ephraimite War; Damascus Document; Ambiguity; Reception

DOI: $10.14712 / 23363398.2020 .7$

$\mathrm{T}$ he purpose of this article is to explain the use of the quotation from Isa 7:17 in the writings from Qumran. This quotation is used twice in the Damascus Document (CD) and the wording is very close to the Masoretic Text in both instances. However, the use of this quotation in two different types of texts (Admonishments in CD VII and Laws in CD XIII) begs an explanation in terms of exegetical approach of the author. I argue that the author of CD knew the larger passage of 
Isa 7, was aware of its ambiguity in multiple senses, found continuity with his current situation, but also left a new ambiguity observable by comparing CD VII and CD XIII.

\section{Function of Isa 7:17 in the Biblical Book}

Chapters 7-12 of the Book of Isaiah capture the events of the socalled Syro-Ephraimite war and verse 7:17 is part of a prophetic speech, where Isaiah talks with the king Ahaz in the moment of distress during the war, while the capital city is under siege by the Assyrian armies.

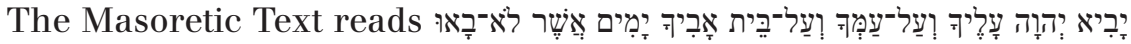

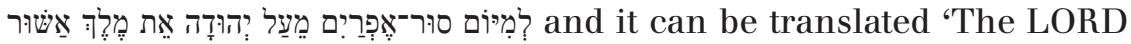
shall bring upon you and your people and your father's house such days as have not come since Ephraim seceded from Judah (the king of Assyria)'. ${ }^{1}$ I want to demonstrate that this biblical verse, as reported in the MT, is ambiguous. It is not clear whether it announces a punishment, or anticipates a hopeful promise regarding an upcoming salvation. Such an ambiguity of the text reflects the complexity of the historical situation and correlates with the description of the events in Isa 7:1-17. This text captures conflicting positions defended by the king and by people. Ambiguity, or uncertainty, is visible on three different levels. 1. The actual formulation of the text in the given verse (morphology and syntax). 2. Content and meaning of the verse. 3. Context and incorporation of the verse into the larger episode. The second part of my paper will evidence as to how the author of the Damascus Document deals with these three ambiguities.

\subsection{Formulation of the Verse}

Ambiguity or uncertain meaning of the text is conditioned, in the first place, by its equivocal grammar. The text is unclear from the grammatical point of view, in the sense that one verb governs two direct objects: the LORD shall bring days and the LORD shall bring the king of Assyria. Such a grammatical oddity is addressed by the BHS apparatus that suggests reading the words the king of Assyria as a secondary addition to the text. This position is shared by several modern exegetes ${ }^{2}$

All translations into English are taken from the NAB, unless otherwise noted.

Ronald E. Clements, Isaiah 1-39: Based on the Revised Standard Version, NCBC (Grand Rapids: Eerdmans, 1982), 89; Hans Wildberger, Isaiah: A Continental Commen- 
and translations that offer various solutions: the NAB puts these words in brackets, understanding them as a gloss. The RSV separates them by a hyphen, without clarifying, though, the syntactical link with the verse. The German EIN moves these words to the middle of the verse, changing them from a direct into an indirect object, but leaving them in brackets. The CEP reads the first object יִמִים as an adverb of time and adjusts the text by adding the demonstrative pronoun 'v téch dnech'. At the same time, the second object (the king of Assyria) is preserved. The Italian CEI translation repeats the same verb twice, altering thus the MT 'manderà ... giorni, ... manderà il re d'Assiria'. The Latin Vulgate translates 'cum rege Assyriorum', understanding the Hebrew particle אֵ not as a direct object marker, but due to a different vocalization, as the conjunction 'with'.

Another, rather marginal problem is the rare expression לִִִִיוֹם that combines two Hebrew prepositions (lamed and min). Both ancient and modern translations opt for simplifying this expression, similarly to other instances in the OT (Judg 19:30; 2 Sam 7:6).

\subsection{Content and Meaning of the Verse}

Besides the unclear grammatical formulations within the verse, even its meaning is somewhat vague. The wording does not allow for deciding whether the days have a positive or a negative content. Days could mean the days of prosperity experienced by Israel during the time of the united monarchy under David and Solomon, which ended in the moment of the division of the monarchy after the death of Solomon. Then, the verse envisions a return of the better days which were experienced by Israel prior to the split of the monarchy.

On the other hand, the days can be taken in a negative sense as days of visitation, or punishment. Such a negative connotation would evoke the very instant of the division of the monarchy as a catastrophic moment that ended the previous prosperity. Even the brief addition about the king of Assyria at the end of the verse appears to support this position, especially if it is read as a new subject, or as an explanatory gloss: 'The LORD shall bring ... days, [which means] ... the king of Assyria' particularly if the Assyrians are perceived as a chastisement (as they typically are in the OT, e.g. Isa 10:5). Even the expression 'bring

tary (Minneapolis: Fortress, 1991), 287; Willem A. M. Beuken, Jesaja 1-12, HThKAT (Freiburg: Herder, 2003), 207. 
upon you' is best explained as anticipating punishment, since the He-

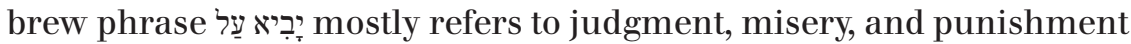
(Gen 27:12; Deut 28:45).

Due to the meager description of these days in the text, as well as an unclear function of the Assyrians in the entire scenario, it is impossible to decide between a positive and a negative significance of these days and thus of the whole verse.

\subsection{Incorporation of the Verse into the Larger Context of Isaiah 7:1-17}

Exploring the incorporation of the verse into the larger episode of Isaiah 7:1-17, an explicit interpretation is not found, and thus it can still be read in both a positive as well as a negative sense, coinciding with the fact that even the entire episode oscillates between these two opposite poles.

A positive interpretation of v. 17 within the episode can be substantiated by its immediate link with the previous verses. The promise of the birth of a son, who will receive the name Emmanuel (Isa 7:14) and soon will have access to curds and honey (Isa 7:15) continues through v. 17, where the Lord brings the days of prosperity upon Judah. Such a prosperity has not been experienced since the time when the northern tribes separated from Judah under the successors of Solomon. ${ }^{3}$ This prosperity is captured in v. 15 and repeatedly stressed in v. 16-17. Together these verses are introduced by the particle wִּ, while v. 17 beginning without a conjunction - can be read as a continuation or a closer explanation of v. 16. The positive outlook from v. 15 is further developed and includes two aspects: punishment for the enemies of Judah and prosperity for Achaz and his people.

Another reading, however, is possible as well and v. 17 can be read in a negative sense within the context of the episode. Even though, from the formal point of view, v. 16-17 develop v. 14-15, their relationship is not evident on the level of content: we learn nothing new about the mother of the child, nor about his name (Emmanuel). The only established connection exists on the level of time ('before the child learns ...' Isa 7:16), but not logic. Even the content of the promise itself (curds and honey; Isa 7:15) might have a negative meaning: although it is often

3 J. J. M. Roberts, First Isaiah. A Commentary, ed. Peter Machinist, Hermeneia (Minneapolis: Fortress, 2015), 120. 
used as a symbol of prosperity (country flowing with milk and honey), curds and honey might as well be a symbol of desolation, in which they are the only foods available, where one has to live off the land (Isa $7: 22),{ }^{4}$ and thus this promise regarding the curds and honey might even evoke the sense of a time of punishment. Such a negative reading would align with the fact that Ahaz is punished for his lack of faith and trust. ${ }^{5}$ The relationship between verses $16 \& 17$ remains unclear, and this problem has been previously addressed by translations in antiquity. While v. 16 speaks of punishment for the enemies of Judah ('the land of those two kings whom you dread shall be deserted'), v. 17 focuses on Ahaz and his people. This contrast between v. $16 \& 17$ is already visible in the Septuagint (v. 17 starts with the adversative conjunction $\dot{\alpha} \lambda \lambda \dot{\alpha}$ ), as well as in the 1QIsa scroll from Qumran which preserves the reading with the adversative waw (ויביא).

This ambiguity of the verse (announcement of punishment, vs promise of salvation) reflects the tension present in the episode, where the king Ahaz as well as his people face a test and they all have to make a decision. The verse as such is part of the prophet's speech where the king Ahaz receives a response and a promise. This speech is a reaction to his lack of faith and his doubts, but the prophet's speech also connects to the previous challenge of the people who hesitate as well. The beginning of the text in Isa 7 puts both the king and the people on the same level: 'his heart and the hearts of his people shook' (Isa 7:2). The entire incident comprises a test for both the king and his people; Isaiah addresses the people along with the king: 'Unless your [pl.] faith is firm, you [pl.] shall not be firm' (Isa 7:9). It is a language that is typical for promises associated with David's monarchy (1 Sam 25:28; 1 Kings 8:26; Isa 55:3) and the preservation of the monarchy concerns the people as well as their kings. Within this context of political instability, both the king and the people have an opportunity to decide. King Ahaz is challenged directly: 'Ask for a sign from the LORD, your God; let it be deep as Sheol, or high as the sky!' (Isa 7:11). Ahaz is allowed to choose from amongst the entire world reality expressed by the merism Sheol ... sky, but he refuses to ask for a sign: 'I will not ask! I will not tempt the LORD!' (Isa 7:12). Refusing to ask for a sign is significant,

Brevard S. Childs, Isaiah (Louisville: Westminster, 2001), 68.

Otto Kaiser, Isaiah 1-12, The Old Testament Library (Philadelphia: Westminster, 1972), 104. 
as it implies not making a decision, or refusing to trust in the Lord. Consequently, the promise is extended to include the people as well: 'Listen, house of David! Is it not enough that you weary human beings? Must you also weary my God?' (Isa 7:13). The call to listen (in plural) is addressed to the house of David. It is a metonymy for the king, who, as a collective personality, embodies the entire people. The fate of the king and his people are linked and they are both a part of the conclusive statement in v. 17.

Facing this challenge, the king and the people will fare differently. The sign given to Ahaz (Isa 7:10-17) indicates both salvation and damnation. Ahaz refuses to trust and to be an obedient son and therefore the Lord promises another son. The sign of Emmanuel will mean downfall for the king (Isa 7:17), but a promise for those who believe (Isa 7:16). ${ }^{6}$ The people will stand the test much better and at least a remnant will be saved, as indicated at the beginning of the episode: the LORD said to Isaiah: 'go out to meet Ahaz, you and your son Shear-jashub' (Isa 7:3). An explicit interpretation of the ambiguous name Shear-jashub follows much later in the text: 'A remnant will return, the remnant of Jacob, to the mighty God' (Isa 10:21). This remnant is a symbol of the portion of Israel which will survive the Assyrian invasion (Isa 10:20-23) and is also a symbol of the people of God (Isa 8:18).

\section{The Use of Isaiah 7:17 in Qumran}

The ambiguities of the biblical text of Isa 7:17 are reflected in the Qumran documents as well and the authors deal with these issues in various ways. Besides being found in biblical manuscripts (the scroll 1 QIsa), verse Isa $7: 17$ is preserved as a quotation in two fragments (4Q266 and 4Q267) of a major document customarily called the Damascus Document (CD).

Scholarly studies of this document are based on its content and divide it into two sections: Admonitions and Laws. Admonitions (CD I-VIII; $\mathrm{XIX}-\mathrm{XX}$ ) present a parenesis based on a reflection of Israel's history. These admonitions describe not only the past and future punishments, but also the salvation of the people. The Laws (CD IX-XVI) are developed based on biblical rules and legislations regarding the organization of the community. The exact relationship between these two types of text

6 Childs, Isaiah, 68-69. 
has not been convincingly demonstrated by scholars, although several hypotheses are defended. ${ }^{7}$ The Qumran discoveries prove, however, that, already in antiquity, the Admonitions, along with the Laws, were part of one literary composition; some of the Qumran fragments contain parts of both works, e.g. 4Q266 and 4Q270.

The quotation from Isa 7:17 is contained in two independent texts one belongs to the Admonitions and the other to the Laws. In both instances the author integrates the biblical quotation into a new context and has to deal with the ambiguity, or lack of clarity of the biblical text. Based on my analysis I argue that the author of CD approaches this ambiguity in two different ways: it is an obstacle to overcome, but also an opportunity of which to take advantage. While addressing the obscurity of the biblical text, the author of CD creates a new ambiguity.

\subsection{Isaiah 7:17 in CD VII}

The text of CD VII is conventionally called Amos-Numbers midrash and the quotation from Isa 7:17 is incorporated into it. The midrash is framed by a warning for those who attempted to enter into the community, but eventually failed to do so (CD VII, 9b-10a and CD VII, 21bVIII, 1a). This warning is justified in the central part of the text, which is sometimes considered a secondary addition. ${ }^{8}$ This justification is substantiated by four biblical quotations (Isa 7:17; Amos 5:26-27; 9:11; Num 24:17) and these quotations are adjusted so as to fit into and support the current argumentation. The pesher technique is used in some instances, while otherwise there are more extensive passages from the biblical texts inserted into the midrash ${ }^{9}$.

The text of Isa 7:17 is used as a fulfilment quotation, or a proof-text, and the weight of this argument is augmented by the adjustments made to the biblical text. By interpreting the biblical text and demonstrating its relevance for the audience, the author deals with the ambiguity of the biblical text.

7 Michael A. Knibb, 'The Place of the Damascus Document,' in Methods of Investigation of the Dead Sea Scrolls and the Khirbet Qumran Site: Present Realities and Future Prospects, ed. Michael O. Wise et al., Ann. N.Y. Acad. Sci. 722 (New York: New York Academy of Sciences, 1994), 151-52.

8 Philip R. Davies, The Damascus Covenant: An Interpretation of the 'Damascus Document,' JSOTS 25 (Sheffield: JSOT Press, 1983), 144.

9 Steven D. Fraade, 'Midrashim,' in Encyclopedia of the Dead Seas Scrolls, ed. Lawrence H. Schiffman and James C. VanderKam (Oxford: University Press, 2000), 550. 
In order to make the biblical text intelligible, the author of CD addresses the problems caused by the obscure formulations (morphology and syntax on the level of the text). The difficult expression לִ לִיִיוֹם substituted by its simpler form מיום ${ }^{10}$ Furthermore, the author of CD omits the tetragrammaton יהוה is theologically motivated, resulting from respect towards this divine name. ${ }^{12}$ This omission of the tetragrammaton also changes the subject of the sentence: instead of 'the Lord shall bring', we read in CD 'the days will come'. As a result of this change, the verb in singular (יבוא) is associated with the subject in plural (ימים). Although it is not necessarily to be viewed as a scribal error, ${ }^{13}$ the result still remains that the author of CD creates a new problem in the syntax of the text.

Another obscurity in the formulation or meaning of the biblical text can be detected in the use of the words 'the king of Assyria' at the end of the verse Isa 7:17 - the author of CD resolves it by leaving these words out of his text. I have previously pointed out that these words appear as a gloss in the biblical text, but they still serve the purpose of lending to the verse a negative meaning. Redactional criticism works with the thesis that the final version of Isa 7 goes back to the period of the religious reform under the king Josiah. ${ }^{14}$ Although it remains impossible to determine the biblical text available to the author of CD (a physical manuscript, or a memorized text), textual criticism can be of a help here. The presence of this addition is attested in the large Qumran scroll of Isaiah (1QIsa), as well as in ancient versions (LXX, Syr). Therefore, it

10 All texts from the Damascus Document are taken from Joseph M. Baumgarten and Daniel R. Schwartz, 'Damascus Document,' in The Dead Sea Scrolls: Hebrew, Aramaic, and Greek Texts with English Translations, ed. James H. Charlesworth, PTSDSSP 2 (Tübingen: Mohr Siebeck, 1995), 4-79. In consideration is taken the reconstruction of Florentino García Martínez and Eibert J. C. Tigchelaar, eds., The Dead Sea Scrolls: Study Edition (Leiden: Brill, 1998). All translations are my own.

11 Something similar is perhaps visible already in the Septuagint, where the general divine name ó $\theta \varepsilon o ́ s$ is used instead of the anticipated кúpı̌s.

12 The same phenomenon is also attested in other instances in the Qumran documents, especially in legislative texts: Donald W. Parry, 'Notes on Divine Name Avoidance in Scriptural Units of the Legal Texts of Qumran,' in Legal Texts and Legal Issues: Proceedings of the Second Meeting of the International Organization for Qumran Studies Cambridge 1995 Published in Honour of Joseph M. Baumgarten, ed. Moshe J. Bernstein, Florentino García Martínez, and John I. Kampen, StTDJ 23 (Leiden: Brill, 1997), 437-49.

13 Eibert J. C. Tigchelaar, 'The Cave 4 Damascus Document Manuscripts and the Text of the Bible,' in The Bible as Book: The Hebrew Bible and the Judean Desert Discoveries, ed. Edward D. Herbert and Emanuel Tov (London: British Library, 2002), 96.

14 Marvin A. Sweeney, Isaiah 1-39 with an Introduction to Prophetic Literature, The Forms of the Old Testament Literature 16 (Grand Rapids: Eerdmans, 1996), 150. 
is permissible to work with the assumption that the author of CD left these words out intentionally, or rather finished his quotation before this particular gloss. By omitting these words, the author provides an actualization of the biblical text: he skips the reference to the king of Assyria which would have been irrelevant in the period of composition (around 2nd century BCE) and might possibly have created an obstacle to understanding.

At first glance, it appears that the author of CD endorses a positive reading of this verse (he removes one of the main arguments in favor of its negative reading). Considering the immediate context, however, leads one to the opposite conclusion. CD VII, 9 speaks about punishment for the evil ones, and this is confirmed by the quotation from Isa $7: 17$. In the most immediate sense, the author of CD leans towards the negative understanding of the given verse and 'the days to come' are days of an unprecedented punishment. Such an interpretation is achieved by clarifying the meaning of the historical context of the days which are about to come. The author clearly understands them not as a time of prosperity during the united monarchy, but as a punishment and tribulation that was incurred after the separation. In fact, the text that follows contains an immediate explanation: 'when the two houses of Israel separated, Ephraim departed from Judah. And all the backsliders were delivered up to the sword' (CD VII, 13). The ambiguity of the biblical text, as previously described, is removed and the author opts for the negative interpretation of the text in his composition.

What remains unaltered is the ambiguity on the level of the entire episode as observed in Isa 7 : the moment of decision by the king as well as by the people. The author of CD finds a continuity between the tension in the biblical text and the tension in the new situation which he is writing about. The situation in CD, the tension and separation of those who originally used to comprise a portion of the community, but who eventually decided not to follow God's commandments, is interpreted from the perspective of Isaiah's prophecy: punishment is envisioned for those who separated from the covenant. The biblical citation acts as a warning to those who are faithful and face difficulties in the present: it highlights the final destiny of the enemies, who otherwise seem to prosper. ${ }^{15}$ The author of CD finds a connection between the larger

15 James C. VanderKam, 'To What End? Functions of Scriptural Interpretation in Qumran Texts,' in Studies in the Hebrew Bible, Qumran, and Septuagint Presented to Eugene 
context of Isa 7 and CD VII in the focus on decisions. Both the king and the people face this challenge in Isa 7, in which the king (and his court) fail, but at least the people are saved (Isa 10:20-22). The audience of CD (the community of Israel in the author's presence) goes through a similar process: those who did not enter into the community ('those who rejected' CD VII, 9) align with those who failed in the past. On the other hand, those who entered into the community will be saved by escaping to the land of the north (CD VII, 14).

The author is able to connect the biblical text to the present audience because of his understanding of history, of biblical texts, and of prophecies in particular. The Damascus Document understands the origin of its own community as the goal and pinnacle of the history of Israel. The continuity with this history ensures a new beginning after a long period of failings and sins. The existence of this community demonstrates a radical reversal of a long series of failings, and the present community is a remnant that preserved faithfulness to God's commandments (CD III, 12-16). ${ }^{16}$ The community is encouraged to persevere in remaining faithful to God's plan, by highlighting the history revealed in the past, which maintains its validity, lest a tragedy will occur. The identity of the community will be preserved by separating from those who are sinful (CD VII, 9) and by fidelity to the covenant. ${ }^{17}$ This small remnant resembles the remnant of people who will be saved in Isa 7 .

Conclusion: The author of CD VII has to contend with the ambiguity of the biblical text when using the quotation from Isa 7 . On the level of the text, he changes the obscure formulations. On the level of the verse, he favors the negative meaning of the text and uses it in the new composition. Although such a choice might appear arbitrary, it is the author's conscious decision, enabled by recognizing the connection with the biblical episode which captures the decision-making process on the part of the king and people facing a test. The author of CD takes

Ulrich, ed. Peter W. Flint, Emanuel Tov, and James C. VanderKam, VT.S 101 (Leiden: Brill, 2006), 317-318.

16 Hermann Lichtenberger, 'Historiography in the Damascus Document,' in History and Identity: How Israel's Later Authors Viewed Its Earlier History, ed. Jan Liesen and Nuria Calduch-Benages, DCL.Y (Berlin: de Gruyter, 2006), 232-233.

17 Peter W. Flint, 'Interpreting the Poetry of Isaiah at Qumran: Theme and Function in the Sectarian Scrolls,' in Prayer and Poetry in the Dead Sea Scrolls and Related Literature: Essays in Honor of Eileen Schuller on the Occasion of Her 65th Birthday, ed. Jeremy Penner, Ken M. Penner, and Cecilia Wassen, StTDJ 98 (Leiden: Brill, 2012), 191. 
a further step by warning those who are in the present community about the consequences of leaving by highlighting the negative example of those who have left the historical community. This latter group is associated with the negative characters of the biblical text, while the positive interpretation of the text is available to those who, being members of the community, are saved by escaping to the land of the north (CD VII, 13).

\subsection{Isaiah 7:17 in CD XIII}

The column CD XIII is part of the Laws (CD IX-XVII) which contain a series of rather independent legislations to determine the functioning of the community. After listing several laws regarding individuals, the portion of the law that relates to 'the whole encampment', or 'the congregation of the encampments for all descendants of Israel' includes the quotation from Isa 7:17 (CD XIII, $20 \mathrm{XIV}, 2) .{ }^{18}$ Even other instances in CD show a repeated legislation for the congregation of the encampments (CD XII, 32; XIV, 3; XIV, 9) and these might reflect the idea of continuity with the historical Israel claimed by the current community.

Due to the damaged state of the text of CD, scholars are only able to follow the basic idea of division within the community (of Israel) and the subsequent punishment, or reward. There is a contrast visible within the members of the community: those who are 'not able to dwell in the land' (CD XIII, 21), as opposed to those who 'walk' (in the prescriptions) (for the Instructor), and God's covenant will protect them (CD XIII, 22). This difference in the fate of these two groups claims a biblical foundation. While the protection of the just ones does not warrant, or does not need any explanation, punishment is explained and justified by two related biblical quotations from Isa 7:17 and Prov 27:12.

The first part of the quoted verse Isa 7:17 has not been preserved and even the consideration of other fragments from Qumran (4Q266 9 III, 16-18; 4Q267 9 V, 2-3; 4Q269 10 II, 6-7) only leads to the conclusion that the quoted text must have been shorter than the current MT. ${ }^{19}$ Thus,

18 This reconstruction is enabled by combination of the fragments from Qumran and the medieval manuscript from Kairo: García Martínez and Tigchelaar, Dead Sea Scrolls, 573.

19 Joseph M. Baumgarten and Józef Tadeusz Milik, The Damascus Document (4Q266273), DJD, XVIII (Oxford: Clarendon, 1996), 70.109; Stephen J. Pfann, Qumran Cave 4 Cryptic Texts, DJD, XXXVI (Oxford: Clarendon, 2000), 204. 
we can presume the reduction of the referent from v. 17a: the original threefold referent 'upon you' (עליך), 'upon your people' (עליך) על בעך), and 'upon the house of your father' (עיך) must have been shortened (based on the available space). The author also adjusts the difficult expression לִיְמיום to a more intelligible one meaning of the verse, the author of CD clearly opts for its negative understanding and takes it as a prediction of punishment. He associates it directly with those who 'will not be able to dwell in the land' (CD XIII, 21) and subsequently talks about punishment, when he quotes from the book of Proverbs: 'the naïve pay the penalty' (CD XIV, 2).

The use of this quotation from Proverbs is made possible by a greater connection that the author finds between Isa 7 and CD XIII. Both texts contain a moment of decision or distinction between right and wrong. This decision might result in a punishment, but at the same time salvation is offered for those who walk, i.e. act according to the instructions (CD XIII, 22). The difference between those who lack knowledge and will be punished and those who will be saved is due to understanding and acting. The members of the community are given a time for keeping the instructions. It is a time of trial and testing and undergoing this period determines their fate. The naïve ones fail this test. It is a category of people who are not supposed to enter into or belong to the community ('stupid, deranged, feeble-minded' CD XV, 15) and thus they 'will not be able to dwell in the land' (CD XIII, 21).

Conclusion: The author of CD XIII works with the ambiguity of the biblical text, but our ability to understand his work is conditioned upon the state of preservation of the text. While attempting to clarify the formulations on the level of the biblical verse, the author goes further and attributes to the verse a negative meaning. The connection with his own context is found in the topics of distinction and decision. Walking according to the instructions gives hope and certitude. On the other hand, those who are condemned receive no hope for a change and are excluded from the country. The quotation from Isa 7:17 only confirms this pessimistic outlook.

\section{Conclusion}

The author of CD appears to use the text from Isa 7:17 in an immediate sense as a fulfillment quotation, without any further explanation. My analysis, however, demonstrates that the author intentionally works 
with this biblical verse. The author is aware of the need to address the problems we have described above. The grammatical difficulty is easily resolved with the author omitting the reference to the king of Assyria, which might have been unintelligible or irrelevant in the new context. The author clearly favors the negative meaning of the verse and uses it in both instances in CD: once in the context of a warning and once in a legislative context. Both of these texts in CD contain the moment of decision making and it is here that the author of CD locates continuity with the episode of Isa 7 which also includes a moment of decision.

By considering each of these texts independently, the author overcomes, incorporates, or takes advantage of the ambiguity of the biblical text. Nevertheless, there is a significant difference between the two texts which is visible within the process of deciding between the positive and the negative characters. CD VII envisions the salvation of the positive characters with their escape into the land of the north. While departure from one's own country is envisioned, the possibility of a return remains open. On the other hand, CD XIII has the negative characters punished by expulsion from the country and their fate is permanent. Although the author of CD does not establish any explicit relationship between these two texts, we can conclude that the quotation from Isa 7:17 retains or rather acquires a new ambiguity similar to those found already in the original episode in Isa 7. The author of CD is able to associate this biblical verse with two different scenarios. This demonstrates that the author knew this biblical text not only as a fulfilment quotation, but considered the entire episode as well. He is aware of its ambiguity and the potential of the biblical text. While overcoming (or taking advantage of) the ambiguity, he creates a new one.

The biblical text is thus regarded by ancient authors not as an artefact to be preserved, but as a living treasure which requires an explanation. By doing so, the author of CD in particular enters into a long line of interpreters which begins within the book of Isaiah (re-reading) and continues through the intertestamental literature, Qumran, and the New Testament. 